\title{
Forage system is the key driver of mountain milk specificity
}

\author{
M. Coppa, ${ }^{1}$ C. Chassaing, ${ }^{1}$ C. Sibra, ${ }^{1}$ A. Cornu, ${ }^{1}$ J. Verbič, ${ }^{2}$ J. Golecký, ${ }^{3}$ E. Engel, ${ }^{4}$ J. Ratel, ${ }^{4}$ A. Boudon, ${ }^{5}$ \\ A. Ferlay, ${ }^{1}$ and B. Martin ${ }^{1 *}$ \\ ${ }^{1}$ Université Clermont Auvergne, INRA, VetAgro Sup, UMR 1213 Herbivores, F-63122 Saint-Genès-Champanelle, France \\ ${ }^{2}$ Agricultural Institute of Slovenia, Hacquetova 17, SI-1000 Ljubljana, Slovenia \\ ${ }^{3}$ Grassland and Mountain Agriculture Research Institute, Mladeznicka 36, 97421 Banska Bystrica, Slovakia \\ ${ }^{4}$ Université Clermont Auvergne, INRA, VetAgro Sup, UMR 370 Product Quality, F-63122 Saint-Genès-Champanelle, France \\ ${ }^{5}$ PEGASE, INRA, Agrocampus-Ouest, 35042, Rennes, France
}

\section{ABSTRACT}

The aims of this work were to determine the effect of upland origin on milk composition when comparing similar lowland and upland production system and to highlight the factors responsible for the added value of upland milk from commercial farms. Tanker milk from 55 groups of farms (264 farms in total) in France, Slovakia, and Slovenia was collected twice during the indoor season and 3 times during the outdoor season. The tanker rounds were selected in each country to be balanced according to their origin (lowland or upland) and within upland or lowland groups, according to the forage systems: corn-based or grass-based forage system. At each milk sampling, the production conditions were recorded through on-farm surveys. The milk was analyzed for gross composition, carotenoids, minerals, fatty acids, phenolic compound derivatives, volatile organic compound concentrations, and color. The milk from upland and lowland areas differed in their contents of a few constituents. Upland milk was richer in not identified (n.i.) retention time (Rt) 13,59, 4-methylpentylbenzene, 1-methyl-2-n-hexylbenzene, and $\beta$-caryophyllene than lowland milk. These differences could be most likely attributable to the utilization of highly diversified and extensively managed semi-natural grasslands. The higher forbs content of upland pastures could be related as well to the richness in C18:3n-3, CLA cis-9,trans-11, MUFA, and PUFA we observed in upland compared with lowland milk during the outdoor season. In contrast, grazing on lowland pastures rich in grasses gave a yellower milk that was richer in $\beta$-carotene. Out of the few compounds showing a significant effect of origin or its interaction, most of the milk constituents were unaffected by the origin at all. However, almost all milk constituents differed

Received April 1, 2019.

Accepted June 10, 2019.

*Corresponding author: bruno.martin@inra.fr according to the forage system and the season, and the differences observed between seasons can be attributed to differences in the cow diet composition.

Key words: dairy cow, upland dairy farm, feeding system, upland milk composition

\section{INTRODUCTION}

Upland (or mountain) areas are characterized by considerable limitations in land-use possibilities mainly due to the difficult climatic conditions, the unsuitability of surfaces for machinery, or a combination of these 2 factors that result in an increase in the cost of farming practices (Santini et al., 2013). Consequently, in these areas, grassland (mostly semi-natural) is the dominant and often the only possible agricultural land use. Upland areas all over the world face a renewed interest for ruminant farming, as their exploitation with livestock does not compete with human food production (Leiber et al., 2014). The delimitation of upland areas is based on minimum altitude thresholds that can vary in each country according to climate and latitude [i.e., in the European Union (EU) it ranges between 600 and 700 $\mathrm{m}$ above sea level (a.s.l.)]. Taking the EU (EU 27) as an example to understand the relevance of upland area for agriculture, here uplands account for $18.5 \%$ of the total surface area and $14.2 \%$ of the total utilizable agricultural area (Martin et al., 2014). Upland areas have $17.8 \%$ of the total EU agricultural holdings, and dairy cows represent approximately $10.5 \%$ of the total dairy livestock units (Santini et al., 2013). To face the higher costs for the production and collection of milk, commercial strategies have been historically adopted to increase the value of upland dairy products [i.e., Protected Designation of Origin (PDO) specification or specific labels for upland productions]. The success of these strategies is revealed in the share of upland dairy products of total economic outputs from the EU dairy sector, which is approximately $12.2 \%$, whereas upland milk production accounts for only $9.5 \%$ of European 
milk (Santini et al., 2013). However, the economic performance of upland dairy farms is often low because of high production costs in upland regions (Santini et al., 2013; Martin et al., 2014).

Several studies have highlighted a specific composition of commercial dairy products from upland origin. Upland milk showed higher n-3 fatty acid (FA), CLA, and lower SFA concentrations, in comparison to lowland milk (Collomb et al., 2002a; Ferlay et al., 2008; Segato et al., 2017). Other studies found upland milk richer in terpenoids (Agabriel et al., 2007) and in fat-soluble vitamins than lowland milk (Segato et al., 2017). Upland cheeses showed also more complex sensory profiles, characterized by a higher number of sensory attributes (Martin et al., 2005; Giaccone et al., 2016), with specific and diversified herbaceous and animal notes, and stronger taste and flavor compared with lowland ones (Bugaud et al., 2002; Martin et al., 2005). The FA and terpenoid profiles were also effective in distinguishing milk according to its lowland or upland origin (Engel et al., 2007; Segato et al., 2017). However, most of this research compared lowland to upland farming systems significantly differing in cow diet composition (proportion of fresh herbage, level of concentrate, type of conserved forages, and so on; Agabriel et al., 2007; Ferlay et al., 2008; Segato et al., 2017). Diet composition and forage quality are relevant factors affecting milk composition and cheese sensory properties (Leiber et al., 2005; Tornambé et al., 2006; Giaccone et al., 2016). Even if single specific and previously mentioned factors in reference to upland conditions have been tested in controlled experiments, their relative importance in commercial farms is still not clear.

The specific sensory properties (Martin et al., 2005; Romanzin et al., 2015) and the positive image of local products are among the factors determining consumers' liking for upland products (Romanzin et al., 2015; Bentivoglio et al., 2019). However, the increasing demand for upland products by consumers and the higher prices paid for them drives the upland dairy farming systems through a progressive intensification (introduction of corn silage, increase in the amount of concentrate in cow diets, use of high yielding specialized breeds, intensive utilization and fertilization of grasslands, and so on; Martin et al., 2014). This intensification trend can affect the sensory properties of upland dairy products (Martin et al., 2005; Giaccone et al., 2016) and may impair consumers' willingness to pay for mountain products. The latter are identified by consumers as specific and useful for biodiversity preservation, landscape maintenance, environmental sustainability, cultural heritage, and ecosystem services in general (Mazzocchi and Sali, 2016; Bentivoglio et al., 2019). It is, however, not clear if or how the specific composition of upland products will be maintained with these trends or if the added value of the upland products is just intrinsic to their upland origin.

Taking advantage of a large-scale, transnational on-farm experiment, the aims of this research were to determine the effect of upland origin on milk composition when comparing similar lowland and upland production systems and to highlight the relative weight of the factors responsible for the specific composition of upland milk from commercial farms.

\section{MATERIALS AND METHODS}

\section{Experimental Design, Milk Sampling, and Data Collection}

The experiment was designed to separate the effect of production in upland areas (upland origin sensu stricto) from the effect of forage system on the composition of commercial milk. The tanker milk from 55 groups of farms (264 farms in total) in France (20 tankers), Slovakia (20 tankers), and Slovenia (15 tankers) was sampled twice during the indoor season and 3 times during the outdoor season. The detailed distribution of farms and tankers in the different countries is described in Chassaing et al. (2016). The tanker rounds were selected according to the characteristics of the farms that were collected within each tanker aiming to have geographically close farms with similar production conditions. The tanker rounds were selected to be balanced according to their origin from lowland or upland areas, using the national regulation definition for upland to establish the altitude threshold, as described by Coppa et al. (2015a): $700 \mathrm{~m}$ a.s.l. in France and $600 \mathrm{~m}$ a.s.l. in Slovenia and Slovakia. In each country and within both upland or lowland groups, the forage system applied in the collected farms, the tanker rounds were balanced between (1) corn silage-based forage system (C), in which corn silage was the dominant forage throughout the year, and (2) grass-based forage system $(\mathbf{G})$, in which conserved grass (hay or grass silage) was fed to dairy cows during the indoor period and cows grazed during the outdoor season.

At each tanker milk sampling, the herd characteristics and performance (number of cows, DIM, and milk yield), diet composition for the lactating cows and altitude of the farm were collected through surveys on each farm that delivered milk to a collected tanker, as described by Chassaing et al. (2016). During the surveys, the average daily quantities of the different conserved forages and concentrates fed to the dairy herd were recorded according to the farmers' declara- 
tions. Fresh herbage intake in pastures was estimated by the difference between the potential intake capacity (Faverdin et al., 2007) and the intake of conserved forages and concentrates. The amounts of the different feedstuffs were finally expressed as a percentage of cow daily DMI.

\section{Milk Sampling and Analyses}

The tanker milk sampling and analyses were detailed by Chassaing et al. (2016). Milk samples were stored at $4^{\circ} \mathrm{C}$ in glass bottles during the transfer to the laboratories (a few hours) where it was divided into 7 subsamples for the analysis of gross composition, FA, minerals, color, carotenoids, and vitamins $\mathrm{A}$ and $\mathrm{E}$, polyphenols, and volatile organic compounds (VOC). The samples were stored without preservative at $-20^{\circ} \mathrm{C}$ until analysis, except for milk gross composition, in which milk fat, protein, lactose, urea, and SCC contents were measured on fresh milk using Fourier transform infrared spectroscopy (MilkoScan FT6000 and Fossomatic FC, Foss, Hillerød, Denmark).

The FA were directly methylated in lyophilized milk (Thermovac TM-20, Froilabo S.A., Meyzieu, France) according to Chassaing et al. (2016). The FAME were injected into a Trace-GC 2000 series gas chromatograph equipped with a flame ionization detector (Thermo Finnigan, Les Ulis, France). The FAME were separated on a $100 \mathrm{~m} \times 0.25 \mathrm{~mm}$ i.d. fused silica capillary column (CP-Sil 88, Chrompack, Middelburg, the Netherlands). The GC conditions were detailed by Chassaing et al. (2016). The peaks were routinely identified by retention time (Rt) comparisons with commercial authentic standards containing a mixture of FAME (NCP \#463, Nu-Chek Prep, Waterville, MN; Supelco \#37, Supelco, Bellefonte, PA, and O5632, Sigma, St. Louis, MO). The sum of trans FA did not include C18:1 trans-11 and CLA cis-9,trans-11.

The analysis of minerals was performed on thawed milk. Sample preparation and mineral extraction were described by Chassaing et al. (2016). The concentrations of $\mathrm{Ca}, \mathrm{Mg}, \mathrm{Na}, \mathrm{K}$, and $\mathrm{Zn}$ in the milk were determined by flame atomic absorption spectroscopy (FAAS, analyst 800, Perkin Elmer, Germany), as described in ISO 8070 (ISO/IDF, 2007) and ISO 11813 (ISO, 1998). The concentrations of $\mathrm{P}$ were determined by measuring the absorbance of a molybdenum-phosphate complex at $430 \mathrm{~nm}$ on a UV/VIS spectrometer (Cary 100, Varian, Mulgrave, Australia). For each mineral, the instrument calibration and accuracy evaluation were described by Chassaing et al. (2016).

Milk color was determined through a Minolta CR310 chromameter (Minolta France S.A., Carrières-sur-Seine,
France), according to Verdier-Metz et al. (2000). The results were expressed using the $\mathrm{L}$, a, b system, where $\mathrm{L}$ (brightness variable) defines the position of the sample on the light-dark axis, a (red index) on the red-green axis, and b (yellow index) on the blue-yellow axis.

To determine $\beta$-carotene, $200 \mu \mathrm{L}$ of milk was diluted in 1,200 $\mu \mathrm{L}$ of 2-propanol containing the internal standard astaxanthin, and butylated hydroxytoluene (BHT) was used as an antioxidant. After $15 \mathrm{~min}$ of mixing followed by centrifugation $(10 \mathrm{~min}, 4,000 \times g$ at $10^{\circ} \mathrm{C}$ ), an aliquot of $25 \mu \mathrm{L}$ from the supernatant was injected into an HP 1100 liquid chromatograph (Agilent Technologies, Palo Alto, CA) with an HP 1100 diode array detector set to $453 \mathrm{~nm}$. The carotenoids were separated on a $2.1 \mathrm{~mm} \times 150 \mathrm{~mm}$ reversed-phase C-30 column. The column temperature was $50^{\circ} \mathrm{C}$. A 2-point calibration curve was made from the analysis of milk calibrators with known carotenoid concentrations. Recovery was over $95 \%$, the method was linear from 0.03 to at least $3 \mu M$, and the limit of detection was $0.04 \mu M$. Residual standard deviation was 2.0 to $11.3 \%$.

The vitamin A content of the milk was determined as described by Chassaing et al. (2016). Milk was hydrolyzed in $12.5 \mathrm{M} \mathrm{KOH} /$ ethanol (2:1 vol/vol) for $25 \mathrm{~min}$ at $80^{\circ} \mathrm{C}$. The BHT was added as an antioxidant. After cooling, retinol was extracted with hexane/toluene (1:1 $\mathrm{vol} / \mathrm{vol}$ ). The extract was then injected into an HP 1100 liquid chromatograph (Agilent Technologies) equipped with an HP 1100 fluorescence detector, emission: 325 $\mathrm{nm}$ and excitation: $480 \mathrm{~nm}$. The vitamin A compounds were separated on a $4.6 \mathrm{~mm} \times 100 \mathrm{~mm}$ normal phase silica column using 2\% 2-propanol in hexane as the mobile phase. A 3-point calibration curve was used for quantification.

The analysis of milk vitamin $\mathrm{E}$ was performed by diluting $1 \mathrm{~mL}$ of milk with $3 \mathrm{~mL}$ of 2-propanol containing the internal standard tocopherol and BHT as an antioxidant. After $15 \mathrm{~min}$ of mixing followed by centrifugation $\left(10 \mathrm{~min}, 4,000 \times \mathrm{g}\right.$ at $\left.10^{\circ} \mathrm{C}\right)$, an aliquot of $20 \mu \mathrm{L}$ of the supernatant was injected into an HP 1100 HPLC-fluorescence detector (Agilent Technologies) equipped with an HP1100 fluorescence detector, emission: $295 \mathrm{~nm}$ and excitation: $330 \mathrm{~nm}$. The tocopherol isomers were separated on a $2.1 \mathrm{~mm} \times 250 \mathrm{~mm}$ reversed-phase column. A 2-point calibration curve was made from analysis of a 3\% albumin solution enriched with known concentrations of tocopherols.

Milk UV-absorbing compounds were extracted with acetonitrile, adapting the procedure of Besle et al. (2010). In addition to phenolic compounds and their derivatives, acetonitrile extracts a wide range of molecules, including nitrogen-containing compounds such as nucleic bases, AA, vitamins, and so on. Briefly, 
$10 \mathrm{~mL}$ of milk was added to $22 \mathrm{~mL}$ of acetonitrile, stirred for $30 \mathrm{~min}$ with vortexing every $15 \mathrm{~min}$, and finally centrifuged for $20 \mathrm{~min}$ at $1,000 \times g$ at $17^{\circ} \mathrm{C}$. The supernatant was evaporated to $0.6 \mathrm{~mL}$ at $45^{\circ} \mathrm{C}$ in a centrifuge evaporator (RC1010, Jouan, Saint-Herblain, France). Deconjugation was performed overnight at $37^{\circ} \mathrm{C}$ with $25 \mu \mathrm{L}$ of a glucuronidase-sulfatase mixture from Helix pomatia G0867 (Sigma, Saint-Quentin Fallavier, France) and $200 \mu \mathrm{L}$ of formate buffer $(0.4 M$, $\mathrm{pH} 5$ ). After adding $1.5 \mathrm{~mL}$ of methanol and vortexing, the tube was cooled on ice for $1 \mathrm{~h}$ to precipitate the enzyme and then centrifuged for $20 \mathrm{~min}$ at $1,000 \times g$ at $7^{\circ} \mathrm{C}$. The supernatant was collected in a calibrated tube and evaporated to $0.4 \mathrm{~mL}$ under nitrogen flow at $45^{\circ} \mathrm{C}$, adjusting the weight to $0.4 \mathrm{~g}$ with water if necessary and adding $0.4 \mathrm{~mL}$ of methanol. The extracts were vortexed, centrifuged for $20 \min \left(1,000 \times g, 7^{\circ} \mathrm{C}\right)$, and filtered through a $0.2-\mu \mathrm{m}$ polypropylene membrane into an HPLC injection vial. The milk extracts were injected into an HPLC-diode array detector system (Waters, Saint-Quentin-en-Yvelines, France). The sample holder was kept at $10^{\circ} \mathrm{C}$. A volume of $20 \mu \mathrm{L}$ was injected into a LichroCART $125 \mathrm{~mm} \times 4 \mathrm{~mm}$ diameter HPLC column containing a SuperSpher 60 RP8-e stationary phase (Merck Chimie SAS, Fontenay sous Bois, France). The elution solvents were A: formic acid $0.1 \%$ in ultra-pure water, and B: formic acid $0.1 \%$ in acetonitrile-water 70:30 (vol:vol). The gradient shifted from $100 \%$ A to $17 \% \mathrm{~B}$ after $3 \mathrm{~min}$, attained $41 \% \mathrm{~B}$ at $26 \mathrm{~min}$, then $46 \%$ at $42 \mathrm{~min}, 51 \%$ at $45 \mathrm{~min}, 54 \%$ at $58 \mathrm{~min}, 86 \%$ at $59 \mathrm{~min}, 86 \%$ at $73 \mathrm{~min}$, finally returned to $100 \% \mathrm{~A}$ within $0.1 \mathrm{~min}$, and stabilized between 73.1 and $87 \mathrm{~min}$, the end of the run. The elution flow rate was $0.35 \mathrm{~mL} /$ min at ambient temperature $\left(20-25^{\circ} \mathrm{C}\right)$. The peaks were identified by comparison to commercial standard Rt and UV spectra (200-400 nm) according to Rouge et al. (2013). A selection of 39 peaks, identified or not, were integrated at $275 \mathrm{~nm}$ using Millenium Software (Waters). Based on their UV spectrum, these peaks comprised 12 simple phenols, 10 benzoic acid derivatives, 5 cinnamic acid derivatives, 3 flavonoids, 3 quinolines, 2 flavins, 1 urolithin, 1 carboline, lumichrome, and 1 unclassified compound. The area values in arbitrary area units were converted to their log values before performing the statistical analyses.

The milk VOC profile was analyzed by solid-phase microextraction (SPME) coupled to GC-MS. For each milk sample, liquid lipid extract was obtained by centrifugation according to Viallon et al. (2000). A 1.2-g aliquot of the lipid extract was kept under nitrogen in a 10-mL vial, each sealed with a butyl-Teflon septum, protected from light, and stored at $-80^{\circ} \mathrm{C}$. The following steps were carried out by SPME/GC-MS with an automated sampler (AOC-5000, Shimadzu, Kyoto, Japan): (1) sample preheating $\left(10 \mathrm{~min} ; 110^{\circ} \mathrm{C} ; 500\right.$ $\mathrm{rpm})$, (2) SPME trapping with a $75-\mu \mathrm{m}$ carboxenpolydimethylsiloxane fiber $\left(30 \mathrm{~min} ; 110^{\circ} \mathrm{C} ; 500 \mathrm{rpm}\right)$, and (3) thermal desorption of the trapped VOC at $280^{\circ} \mathrm{C}$ for $2 \mathrm{~min}$ in the GC inlet. The VOC analysis was performed by GC/MS (6890 GC, 5973A MS, HewlettPackard). The VOC were injected in splitless mode into a DB-5MS capillary column $(60 \mathrm{~m} \times 0.32 \mathrm{~mm} \times 1 \mu \mathrm{m}$, J\&W, Agilent Technologies). The oven temperature was held at $40^{\circ} \mathrm{C}$ for $5 \mathrm{~min}$, increased to $230^{\circ} \mathrm{C}\left(3^{\circ} \mathrm{C}\right.$ $\mathrm{min}^{-1}$ ), and held at $230^{\circ} \mathrm{C}$ for $10 \mathrm{~min}$. The temperature was set at $230^{\circ} \mathrm{C}$ in the GC-MS transfer line, $180^{\circ} \mathrm{C}$ in the MS source, and $150^{\circ} \mathrm{C}$ in the MS quadrupole. The electron impact energy was set at $70 \mathrm{eV}$, and data were collected in full scan mode in the range of 33 to 250 $\mathrm{m} / \mathrm{z}$ at a scan range of $6.2 \mathrm{scans} / \mathrm{s}$. After revealing the VOC markers by statistical treatments, tentative identifications were performed on the basis of both mass spectra by deconvolution using AMDIS software (version 2.72 ; http://www.amdis.net/), comparison against the NIST/EPA/NIH Mass Spectral Library (NIST 14, https://chemdata.nist.gov/), and linear retention indices (LRI) by comparison against published LRI values and those of our internal database. Peak area integration of the candidate markers was performed with MSD ChemStation (version D.01.02.1; Agilent Technologies) using a mass fragment selected as being specific and free of any coelution. The parameters used for the tentative identification of the VOC are reported in Table 1.

\section{Statistics}

Statistical analysis of the data related to milk composition was performed with SAS software (version 8.6, SAS Institute Inc., Cary, NC). The experimental design allowed treatment of all the data for production conditions and milk composition by ANOVA using a mixed model, in which the season, forage system, and origin were the fixed factors and the sampling period nested within the season was the repeated factor. The tanker round was used as the statistical unit. At each sampling period, survey data collected from the farms belonging to a tanker were averaged and the mean value was attributed to the tanker. All the interactions (namely, season $\times$ forage system, season $\times$ origin, forage system $x$ origin, and season $\times$ forage system $x$ origin) were also included in the model. The Fisher's $F$ value of each factor/interaction included in the model was used as an indicator of the relative weight of the factor/interaction in determining the model itself (Coppa et al., 2015a). Bivariate Pearson correlations were also used to test the relationship between the concentrations of milk 
constituents and the proportions of different feedstuffs in the dairy cow diet and altitude.

\section{RESULTS}

Tables 2, 3, 4, and 5 give the average data on milk composition according to season, forage system, and origin. Of the 39 analyzed UV-absorbing compounds, Table 4 reports only those significantly influenced by the studied factors. Table 6 gives the corresponding data on the production conditions.

\section{Seasonal Variations}

Season significantly affected several milk constituents. The milk produced during the outdoor season was the richest in vitamins $\mathrm{E}$ and $\mathrm{A}, \mathrm{C} 18: 0$, branched-chain fatty acids (BCFA), 3,4-dimethylphenol, toluene, 2 -methyl-1H-indole, $\alpha$-thujene, $\beta$-citronellene, sabinene, $\alpha$-copaene, caparratriene, iso-caryophyllene, and 10,10-dimethyl-4-acetyl-tricyclo[5.2.1.0 $(1,5)]$ decane, was the brightest (L), had the lowest $\mathrm{Ca}, \mathrm{Mg}, \mathrm{P}$, and $\mathrm{K}$, 2,6-quinolinediol, flavin Rt 15.80, riboflavin, 1-methyl3 -carboxy- $\beta$-carbolin, and 2,4-quinolinediol contents and had lower n-6/n-3 ratio.
The concentrate proportion of the cow diet was lower during the outdoor than the indoor season (19 vs. $23 \%$ on a DM basis).

\section{Forage System Effect}

The forage system significantly affected the concentrations of most of the milk constituents. The tanker round milk from the farms that adopted a grass-based forage system was richer in C18:0, C18:3n -3 , BCFA, cymene isomer, $\alpha$-thujene, $\beta$-citronellene, sabinene, $\alpha$-copaene, caparratriene, iso-caryophyllene, $\beta$-caryophyllene, $\alpha$-humulene, and 10,10-dimethyl4-acetyl-tricyclo[5.2.1.0(1,5)]decane, had a higher C18:1 cis-9/C16:0 ratio, and had a lower content of vitamin E, K, SFA, and 1-methyl-3-carboxy- $\beta$-carboline, 4-methylpentyl-benzene, and a lower $\mathrm{n}-6 / \mathrm{n}-3$ ratio when compared with milk from the corn-based forage system.

The proportions of concentrates was lower (18 vs. $24 \%$ of diet DM).

\section{Origin Effect}

Upland and lowland milks were globally similar, except for the concentrations of not identified (n.i.)

Table 1. Parameter used for the tentative identification of volatile organic compounds

\begin{tabular}{|c|c|c|c|c|}
\hline Volatile organic compound & Identification $^{1}$ & $m / z^{2}$ & $\mathrm{LRI}^{3}$ & $\mathrm{CAS}^{4}$ \\
\hline \multicolumn{5}{|l|}{ Ketone } \\
\hline 2,3-Octanedione & m-sp, LRI & 99 & 982 & $585-25-1$ \\
\hline \multicolumn{5}{|l|}{ Aromatic compound } \\
\hline Toluene & m-sp, LRI & 91 & 771 & $108-88-3$ \\
\hline Benzonitrile & m-sp, LRI & 76 & 993 & $100-47-0$ \\
\hline Cymene isomer & m-sp, LRI & 119 & 1,033 & \\
\hline 4-Methylpentyl-benzene & m-sp, LRI & 91 & 1,172 & $4215-86-5$ \\
\hline 1H-indole & m-sp, LRI & 117 & 1,309 & $120-72-9$ \\
\hline 1-Methyl-2-n-hexyl-benzene & m-sp, LRI & 105 & 1,380 & $1595-10-4$ \\
\hline 2-Methyl-1H-indole & m-sp, LRI & 130 & 1,408 & $120-72-9$ \\
\hline \multicolumn{5}{|l|}{ Monoterpenoid } \\
\hline$\alpha$-Thujene & m-sp, LRI & 93 & 931 & $2867-05-2$ \\
\hline$\alpha$-Pinene & m-sp, LRI & 93 & 942 & $80-56-8$ \\
\hline Sabinene & m-sp, LRI & 93 & 981 & $3387-41-5$ \\
\hline$\beta$-Citronellene & m-sp, LRI & 67 & 944 & $2436-90-0$ \\
\hline \multicolumn{5}{|l|}{ Sesquiterpenoid } \\
\hline$\alpha$-Copaene & m-sp, LRI & 105 & 1,400 & $14912-44-8$ \\
\hline Caparratriene & m-sp & 163 & 1,405 & $172549-29-0$ \\
\hline Iso-caryophyllene & m-sp, LRI & 93 & 1,434 & $118-65-0$ \\
\hline$\beta$-Caryophyllene & m-sp, LRI & 93 & 1,453 & $87-44-5$ \\
\hline$\alpha$-Humulene & m-sp, LRI & 93 & 1,490 & $6753-98-6$ \\
\hline Germacrene D & m-sp, LRI & 161 & 1,501 & $23986-74-5$ \\
\hline 10,10-Dimethyl-4-acetyl-tricyclo[5.2.1.0(1,5)]decane & m-sp & 163 & 1,525 & \\
\hline$\delta$-Cadinene & m-sp, LRI & 161 & 1,542 & $483-76-1$ \\
\hline
\end{tabular}

${ }^{1}$ Tentative identification based on mass spectrum (m-sp), linear retention index (LRI) from the literature, or internal databank.

${ }^{2}$ Mass fragment used for abundance determination.

${ }^{3}$ Linear retention indices on a DB5 capillary column.

${ }^{4} \mathrm{CAS}=$ Chemical Abstracts Service identification number. 


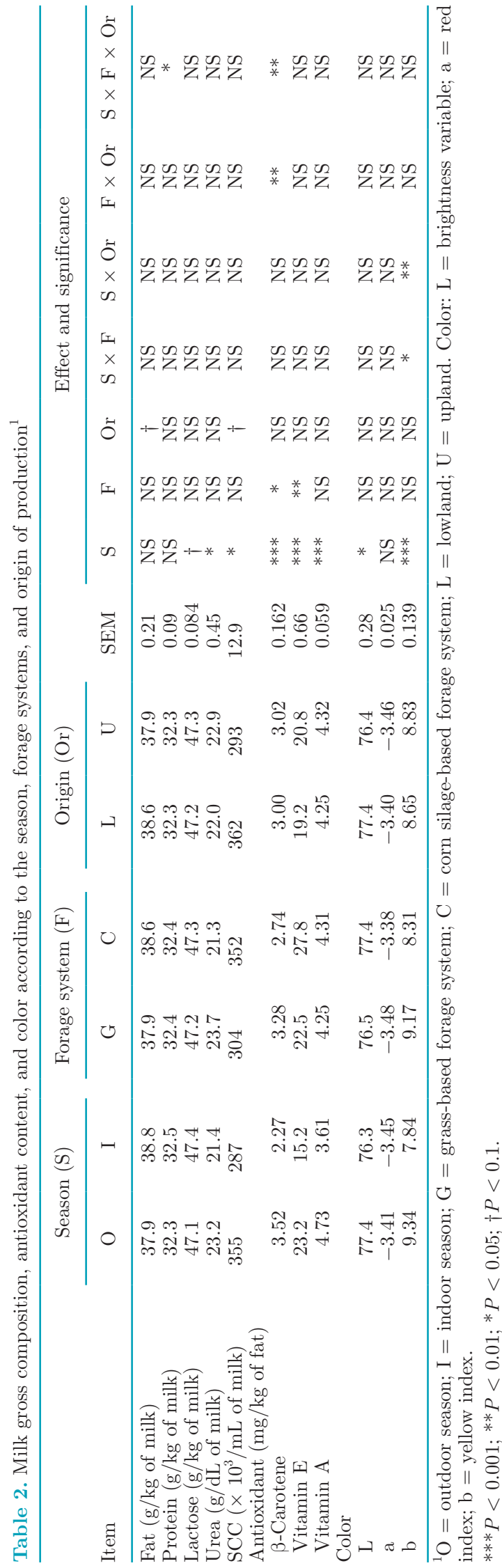

benzoic compound Rt 13,59, 4-methylphenylbenzene, 1-methyl-2-n-hexylbenzene, and $\beta$-caryophyllene that were higher in upland than in lowland milk. Farms included in the upland tanker round reared a larger proportion of local breeds and cows had higher lactation rank and received lower proportions of corn silage in the diet (16 vs. $22 \%$ of diet DM).

Several significant interactions were observed for both milk constituents and production conditions for season and forage system effects, whereas only a few significant interactions were observed between the effect of origin and the other factors.

\section{Interaction Between Season and Forage System}

Season affected differently several milk constituents according to the forage system (Table 7). In particular, during the outdoor season, the G milk was yellower (b) and richer of CLA cis-9,trans-11, PUFA, trans FA, and n.i. Rt 51.8, when compared with $\mathrm{C}$ milk. In parallel $\mathrm{G}$ cows received higher pasture and lower grass silage proportion. All these parameters were similar in $\mathrm{G}$ and $\mathrm{C}$ forage systems during the indoor season. During the indoor season, $\mathrm{C}$ milk was richer in de novo synthesis FA, and poorer in C18:1 cis-9, when compared with G milk, and the latter was richer in 1-methyl-2-n-hexylbenzene. In parallel, $\mathrm{G}$ cows were fed with higher hay proportion. The differences between $\mathrm{C}$ and $\mathrm{G}$ milk for C16:0 and C18:1 trans-11 were greater during the outdoor than during the indoor season, whereas it was the opposite for milk yield and corn silage proportion in cow diet.

\section{Interaction Between Season and Origin}

Season affected differently some milk constituents according to their origin (Table 8). During the outdoor season, upland milk was richer in C18:1 cis-9, C18:3n-3, CLA cis-9,trans-11, MUFA, PUFA, and n.i. Rt 51.89, and had a higher $\mathrm{C} 18: 1$ cis-9/C16:0 ratio, whereas it was poorer in SFA compared with lowland milk. This last was poorer in $\alpha$-humulene as well. All these parameters were similar in lowland and upland milk during the indoor season. During the indoor season, the upland milk was less yellow (b), and richer in de novo synthesis FA, benzonitrile, and indole than lowland milk. The latter was also poorer in 2,3-octanedione.

\section{Interaction Between Forage System and Origin}

Only a few variables showed a significant interaction between the forage system and the origin of production (Table 9). In $\mathrm{G}$ farms in lowland, winter feeding duration was on average $28 \mathrm{~d}$ shorter than in the other 
Table 3. Milk fatty acid (FA) composition according to the season, forage systems, and origin of production ${ }^{1}$

\begin{tabular}{|c|c|c|c|c|c|c|c|c|c|c|c|c|c|c|}
\hline \multirow[b]{2}{*}{ FA $(g / 100 \mathrm{~g}$ of $\mathrm{FA})$} & \multicolumn{2}{|c|}{ Season $(\mathrm{S})$} & \multicolumn{2}{|c|}{$\begin{array}{l}\text { Forage system } \\
\text { (F) }\end{array}$} & \multicolumn{2}{|c|}{ Origin (Or) } & \multirow[b]{2}{*}{ SEM } & \multicolumn{7}{|c|}{ Effect and significance } \\
\hline & $\mathrm{O}$ & I & G & $\mathrm{C}$ & $\mathrm{L}$ & $\mathrm{U}$ & & S & $\mathrm{F}$ & Or & $\mathrm{S} \times \mathrm{F}$ & $\mathrm{S} \times \mathrm{Or}$ & $\mathrm{F} \times \mathrm{Or}$ & $\begin{array}{l}\mathrm{S} \times \mathrm{F} \\
\times \mathrm{Or}\end{array}$ \\
\hline$\Sigma$ de novo synthesis FA & 23.9 & 25.4 & 24.2 & 24.8 & 24.5 & 24.5 & 0.10 & $* * *$ & $* *$ & NS & * & ** & NS & NS \\
\hline C16:0 & 29.8 & 31.3 & 28.9 & 30.7 & 30.2 & 29.4 & 0.16 & $* * *$ & $* * *$ & $\dagger$ & $*$ & NS & NS & NS \\
\hline C18:0 & 9.83 & 9.16 & 9.79 & 9.33 & 9.32 & 9.80 & 0.068 & $* * *$ & $*$ & $\dagger$ & NS & NS & NS & $\dagger$ \\
\hline C18:2n-6 & 1.54 & 1.56 & 1.53 & 1.57 & 1.54 & 1.56 & 0.020 & NS & NS & NS & NS & $\dagger$ & NS & NS \\
\hline C18:3n-3 & 0.57 & 0.45 & 0.63 & 0.42 & 0.51 & 0.54 & 0.013 & $* * *$ & $* * *$ & NS & NS & ** & NS & NS \\
\hline CLA cis-9,trans-11 & 0.79 & 0.44 & 0.81 & 0.49 & 0.60 & 0.70 & 0.022 & $* * *$ & $* * *$ & NS & $* * *$ & $*$ & NS & NS \\
\hline OCFA & 2.52 & 2.52 & 2.59 & 2.45 & 2.56 & 2.48 & 0.015 & NS & $* *$ & NS & NS & NS & $*$ & NS \\
\hline BCFA & 2.46 & 2.31 & 2.57 & 2.23 & 2.38 & 2.42 & 0.023 & $* * *$ & $* * *$ & NS & NS & NS & NS & NS \\
\hline SFA & 67.5 & 70.7 & 68.1 & 69.4 & 68.9 & 68.6 & 0.17 & $* * *$ & $* *$ & NS & NS & $* *$ & $\dagger$ & NS \\
\hline MUFA & 27.8 & 25.6 & 27.2 & 26.6 & 26.8 & 26.9 & 0.13 & $* * *$ & $\dagger$ & NS & NS & $*$ & $*$ & NS \\
\hline
\end{tabular}

${ }^{1} \mathrm{O}=$ outdoor season; $\mathrm{I}=$ indoor season; $\mathrm{G}$ = grass-based forage system; $\mathrm{C}=$ corn silage-based forage system; $\mathrm{L}=$ lowland; $\mathrm{U}=\mathrm{upland}$; OCFA $=$ odd-chain fatty acids; BCFA = branched-chain fatty acids.

${ }^{* * *} P<0.001 ;{ }^{*} P<0.01 ; * P<0.05 ; \dagger P<0.1$.

groups and the milk was richer in odd-chain FA and poorer in benzonitrile than on upland, whereas the latter was richer in MUFA. Indole was higher in milk from lowland in $\mathrm{C}$ farms, whereas in $\mathrm{G}$ farms it was higher in milk from upland farms. The cows reared in $\mathrm{C}$ farms included in the upland tanker rounds calved later.

\section{Interaction Between Season, Forage System, and Origin}

Only 3 milk constituents showed a significant interaction between season, forage system, and origin (Figure $1)$. During the outdoor season, the protein content of tanker round was higher in $G$ lowland than in $G$ upland milk, whereas during the indoor season the $G$ milk protein content followed the opposite trend. During the indoor season, the $\mathrm{C}$ milk from lowland farms had higher protein content than milk from the upland farms. During the outdoor season, the $\beta$-carotene content was higher in milk from $G$ lowland than $G$ upland farms, whereas in milk from $\mathrm{C}$ farms it followed the opposite trend. However, the $\beta$-carotene content in milk was similar for all the forage systems on lowland and upland farms during the indoor season. During the grazing season, the lumichrome content was higher in G lowland than in G upland milk, whereas it was lower in $\mathrm{C}$ lowland than in $\mathrm{C}$ upland milk. However, the differences between upland and lowland lumichrome content reversed for both forage systems during the indoor season.

\section{Relationship Between Production Conditions and Milk Characteristics}

Figure 2 shows the Fisher's $F$ value of the factors and interactions included in the statistical model for milk constituents that showed significant $(P<0.05)$ or numerical $(P<0.1)$ effect of the origin or of the interactions between origin and other factors. Even when significant, the effect of origin or of its interactions showed largely lower Fisher's $F$ value compared with season, forage system, or season $\times$ forage system. This was much more evident for the constituents having a low unexplained error (i.e., almost all FA, $\beta$-carotene, yellowness, and n.i. Rt 51.89; Figure 2). The Fisher's $F$ of the effect involving origin were relatively higher for n.i. benzoic compound Rt 13,59, lumichrome, indole, and the benzenic VOC, for which, however, the error unexplained by the model was very high (Figure 2).

Table 10 reports the significant Pearson correlation coefficient between the milk constituents and the production conditions. On one hand, the correlations between altitude and the concentrations of the different milk constituents, when significant, showed Pearson correlation coefficients that were always very low (largely $<0.4$ or $>-0.4$ ). On the other hand, the proportion of pasture in the cow diet was positively correlated (Pearson's R $>0.4$ ) with milk yellowness and vitamin E, C18:1 trans-11, C18:3n-3, CLA cis9,trans-11, PUFA, BCFA, n.i. Rt 51.89, toluene, and 10,10-dimethyl-4-acetyl-tricyclo[5.2.1.0(1,5)]decane 


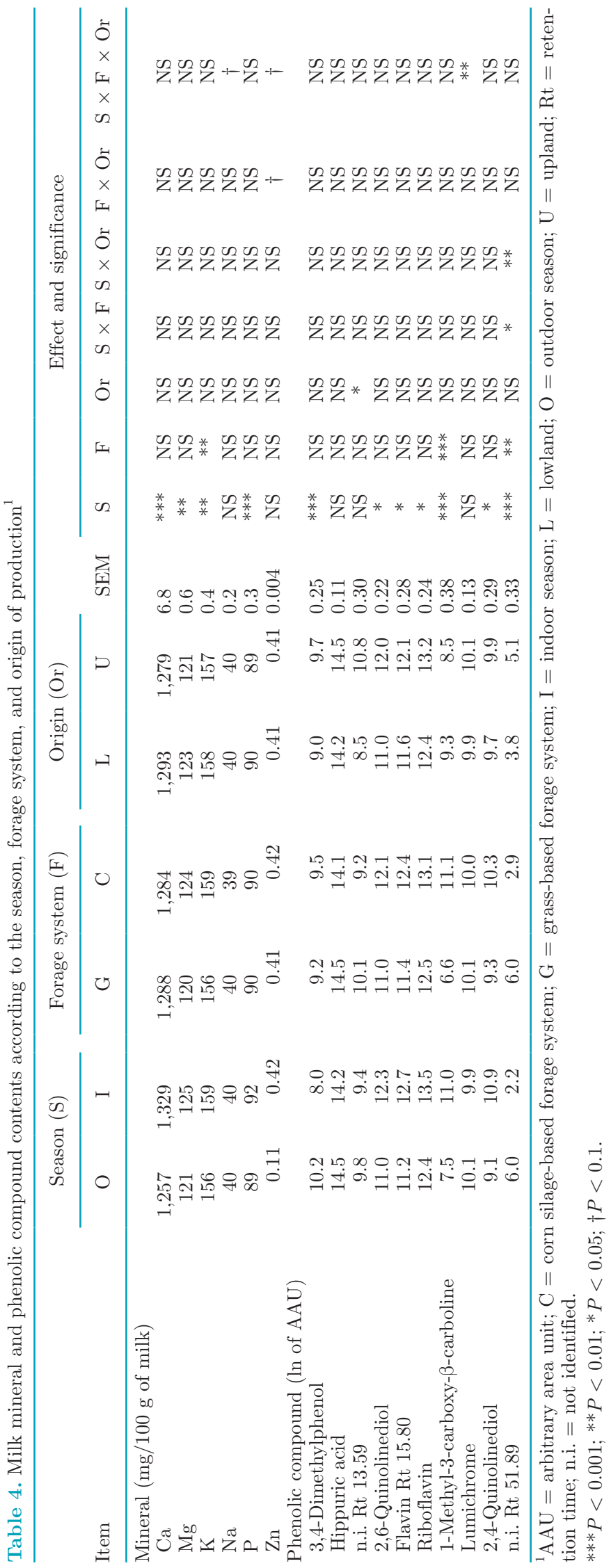

concentrations in milk. It was also negatively correlated (Pearson's $\mathrm{R}<-0.4$ ) with milk C16:0, SFA, and 1-methyl-3-carboxy- $\beta$-carboline contents and the $\mathrm{n}-6 / \mathrm{n}-3$ ratio. The proportion of grass silage showed only negative, in particular with C18:1 trans-11, CLA cis-9,trans-11, PUFA concentrations in milk, and unexpectedly no significant correlation with 1-methyl3 -carboxy- $\beta$-carboline. The proportion of hay in the cow diet was negatively correlated with milk trans-FA (Table 10). Milk yellowness and C18:1 trans-11, C18: 3n-3, CLA cis-9,trans-11, BCFA, PUFA n.i. Rt 51.89, caparritene, $\beta$-caryophyllene, and 10,10-dimethyl-4-acetyl-tricyclo[5.2.1.0 $(1,5)]$ decane contents were negatively correlated and 1-methyl-3-carboxy- $\beta$-carboline, and C16:0 concentrations were positively correlated with corn silage. The n-6/n-3 ratio was positively correlated with the corn silage and concentrate proportions in the cow diet. No significant correlation was observed between grass silage and 1-methyl-3-carboxy- $\beta$-carbolin.

\section{DISCUSSION}

\section{Origin Effect and Its Interactions with Season and Forage System}

In contrast to the results from the literature comparing lowland and upland dairy products (Collomb et al., 2002a; Agabriel et al., 2007; Segato et al., 2017), we found only few differences in the composition of milk produced on upland or lowland areas. Upland milk was richer in several benzenic VOC. Ratel and Engel (2009) also observed higher concentration of this group of compounds in upland milk. These compounds are considered an environmental pollutant (Sexton et al., 2005) and their preferential accumulation at higher altitude could depend on the temperature sensitiveness of the scavenging efficiency of a compound within the range encountered along a mountain slope (Wania and Westgate, 2008; Ratel and Engel, 2009). However, Besle et al. (2010) found higher concentration of benzenic compounds in milk from cow grazing on (or fed hay from) upland grasslands and suggested that they originate from the degradation by the animal metabolism of phenolic compounds, which are much more abundant in dicotyledon-rich upland pasture (Reynaud et al., 2010). The higher value of benzonitrile and indole we observed particularly in upland milk from grass-based feeding system could reinforce this hypothesis. A similar interpretation could be made for the higher content of $\beta$-caryophyllene we found in upland milk regardless of season (Agabriel et al., 2007). Terpenes and phenolic compounds can be directly transferred from plants to milk (Viallon et al., 2000; Besle et al., 2010), and their abundance in upland milk is well documented, espe- 
MOUNTAIN ORIGIN SLIGHTLY AFFECTS MILK COMPOSITION

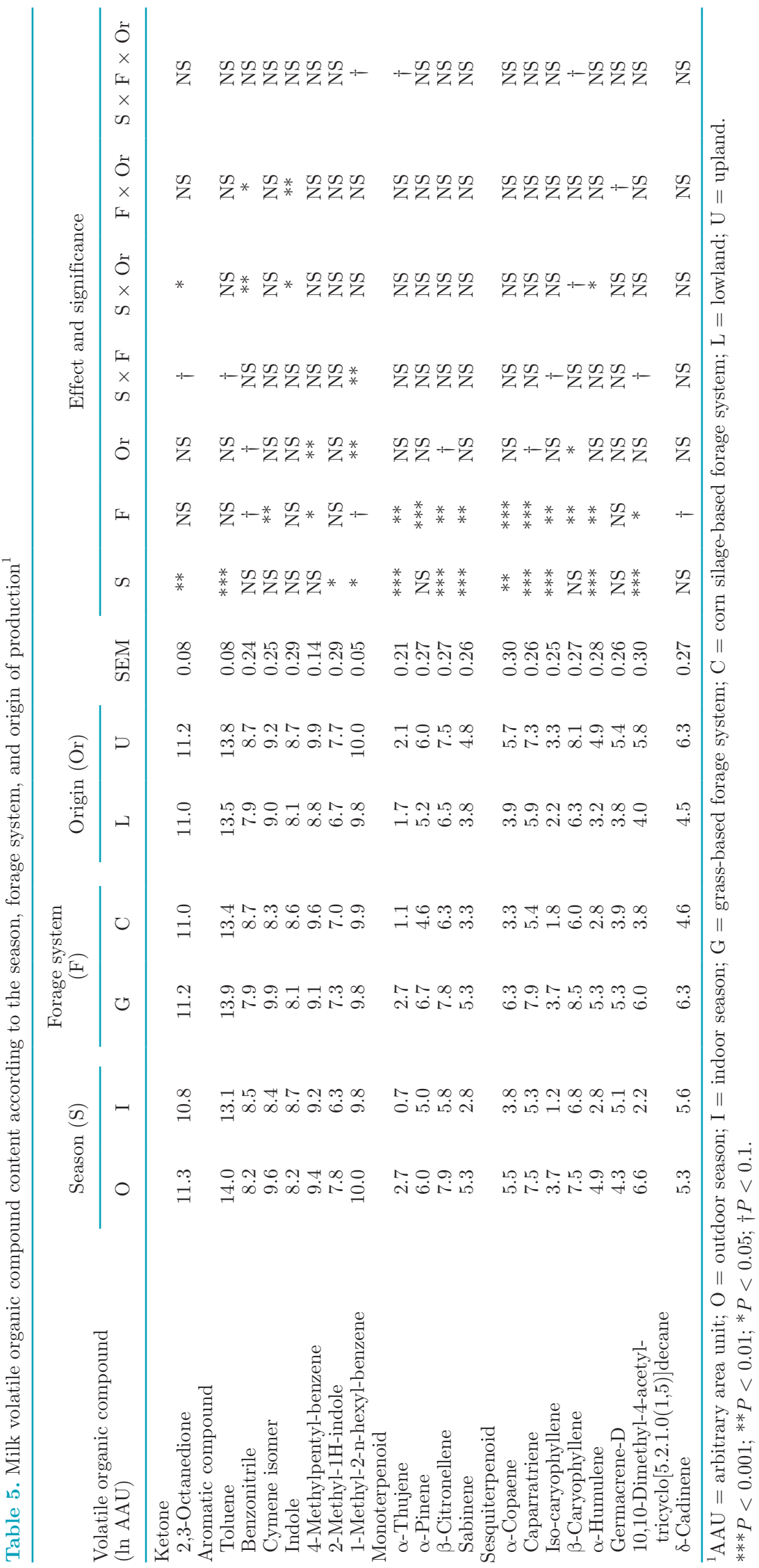




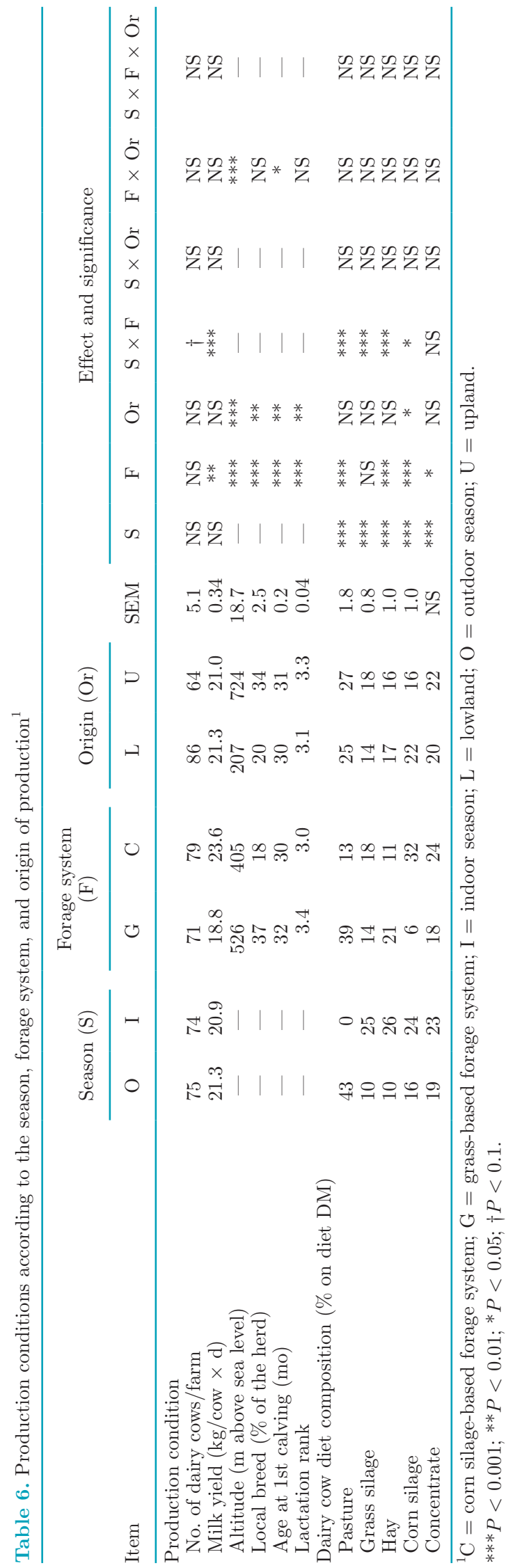

cially at pasture (Tornambé et al., 2006; De Noni and Battelli, 2008; Besle et al., 2010). This is in agreement with the higher concentration of $\alpha$-humulene and n.i. Rt 51.89 we found in upland milk during the grazing season.

The botanical composition of upland pastures could as well be at the origin of the difference we observed in the FA profile between upland and lowland milk during the outdoor season. The richness in secondary metabolite (i.e., terpenes and polyphenols) of the forbs, abundant on upland pastures, can partially inhibit the ruminal biohydrogenation of dietary FA, resulting in a milk richer in C18:3n-3, CLA cis-9,trans-11, MUFA, and PUFA (Collomb et al., 2002b; Leiber et al., 2005; Ferlay et al., 2017), as we found during the outdoor season. Similarly, grazing on pastures rich in grasses, especially at an early phenological stage, gives a yellower milk, richer in $\beta$-carotene (Nozière et al., 2006), as we found in lowland milk during the grazing season. However, the higher $\beta$-carotene content in upland milk from corn silage-based system, compared with the same forage system in lowland could be related to a higher pasture proportion in cow diet (Nozière et al., 2006). The interaction between origin, forage system, and season of lumichrome is more difficult to interpret. Palanuk and Warthesen (1988) identified lumichrome in milk as the result of photodegradation of riboflavin. They also observed that and lumichrome appearance did not follow the same kinetics as riboflavin disappearance, which they attributed to lumichrome degradation. This is in accordance with our results, where milk riboflavin content did not show any significant interaction mirroring the interaction observed for lumichrome.

Out of the few compounds showing a significant effect of origin or its interaction, most of the milk constituents were unaffected by the origin at all. Furthermore, even the affected constituents showed a low relevance of the origin or of the interactions with origin, compared with the relevance of season and feeding system effects or interactions (Figure 2). When the origin significantly affected milk constituents, most of the error of the model remained (Figure 2). This is particularly the case of lumichrome, protein, and benzenic compounds, suggesting that other factors, out of those included in the statistical model could drive the content of these compounds in milk. Even considering that the experimental design was studied to separate the effect of origin sensu stricto for other confounding factors, the relevance of origin on milk composition was lower than expected. This was particularly the case for the grass-based farming systems and during the grazing season, where the fresh herbage proportion of the cow diet increased to over $60 \%$ of diet DM. In our study, origin affected only a small number of UV-absorbing 
Table 7. Milk constituents with significant interactions between the season and forage system of production ${ }^{1}$

\begin{tabular}{|c|c|c|c|c|c|}
\hline \multirow[b]{2}{*}{ Item } & \multicolumn{2}{|c|}{$\mathrm{O}$} & \multicolumn{2}{|c|}{ I } & \multirow[b]{2}{*}{ Significance } \\
\hline & $\mathrm{G}$ & $\mathrm{C}$ & G & $\mathrm{C}$ & \\
\hline \multicolumn{6}{|l|}{ Color } \\
\hline $\mathrm{b}$ & $9.69^{\mathrm{a}}$ & $8.65^{\mathrm{b}}$ & $7.64^{\mathrm{c}}$ & $7.62^{\mathrm{c}}$ & $*$ \\
\hline \multicolumn{6}{|l|}{ Fatty acid (FA; g/100 g of FA) } \\
\hline$\Sigma$ de novo synthesis FA & $23.8^{\mathrm{b}}$ & $24.1^{\mathrm{b}}$ & $24.9^{\mathrm{b}}$ & $25.9^{\mathrm{a}}$ & $*$ \\
\hline $\mathrm{C} 16: 0$ & $27.7^{\mathrm{d}}$ & $29.9^{\mathrm{c}}$ & $30.8^{\mathrm{b}}$ & $31.7^{\mathrm{a}}$ & * \\
\hline C18:1 trans -11 & $2.33^{\mathrm{a}}$ & $1.31^{\mathrm{b}}$ & $1.04^{\mathrm{c}}$ & $0.91^{\mathrm{d}}$ & $* * *$ \\
\hline $\mathrm{C} 18: 1$ cis -9 & $19.4^{\mathrm{a}}$ & $19.5^{\mathrm{a}}$ & $18.8^{\mathrm{a}}$ & $17.9^{\mathrm{b}}$ & $*$ \\
\hline CLA cis- 9, trans -11 & $1.00^{\mathrm{a}}$ & $0.56^{\mathrm{b}}$ & $0.47^{\mathrm{b}}$ & $0.39^{\mathrm{b}}$ & $* * *$ \\
\hline PUFA & $4.48^{\mathrm{a}}$ & $3.57^{\mathrm{b}}$ & $3.44^{\mathrm{bc}}$ & $3.14^{\mathrm{c}}$ & $* * *$ \\
\hline trans $\mathrm{FA}$ & $2.30^{\mathrm{a}}$ & $2.07^{\mathrm{b}}$ & $1.75^{\mathrm{c}}$ & $1.89^{\mathrm{c}}$ & $* *$ \\
\hline \multicolumn{6}{|l|}{ Phenolic compound (ln of AAU) } \\
\hline n.i. Rt 51.89 & $7.77^{\mathrm{a}}$ & $4.03^{\mathrm{b}}$ & $2.52^{\mathrm{b}}$ & $1.18^{\mathrm{b}}$ & $*$ \\
\hline \multicolumn{6}{|l|}{ Volatile organic compound (ln AAU) } \\
\hline 1-Methyl-2-n-hexylbenzene & $9.98^{\mathrm{a}}$ & $9.89^{\mathrm{a}}$ & $9.48^{\mathrm{b}}$ & $9.94^{\mathrm{a}}$ & ** \\
\hline \multicolumn{6}{|l|}{ Production condition } \\
\hline Milk yield $(\mathrm{kg} /$ cow $\times \mathrm{d})$ & $19.6^{\mathrm{b}}$ & $23.6^{\mathrm{a}}$ & $18.3^{\mathrm{c}}$ & $24.1^{\mathrm{a}}$ & $* * *$ \\
\hline \multicolumn{6}{|l|}{ Dairy cow diet composition (\% on DM diets) } \\
\hline Pasture & $64^{\mathrm{a}}$ & $22^{\mathrm{b}}$ & $0^{\mathrm{c}}$ & $0^{\mathrm{c}}$ & $* * *$ \\
\hline Grass silage & $5^{\mathrm{c}}$ & $16^{\mathrm{b}}$ & $25^{\mathrm{a}}$ & $22^{\mathrm{ab}}$ & $* * *$ \\
\hline Hay & $9^{\mathrm{b}}$ & $10^{\mathrm{b}}$ & $39^{\mathrm{a}}$ & $12^{\mathrm{b}}$ & $* * *$ \\
\hline Corn silage & $4^{\mathrm{c}}$ & $27^{\mathrm{b}}$ & $11^{\mathrm{c}}$ & $38^{\mathrm{a}}$ & $*$ \\
\hline
\end{tabular}

${ }^{\mathrm{a}-\mathrm{d}}$ Different superscript letters within the same row indicate differences among values.

${ }^{1} \mathrm{I}=$ indoor season; $\mathrm{O}=$ outdoor season; $\mathrm{G}=$ grass-based forage system; $\mathrm{C}=$ corn silage-based forage system; $\mathrm{AAU}=$ arbitrary area unit; $\mathrm{b}=$ yellow index; $\mathrm{Rt}=$ retention time; n.i. $=$ not identified

*** $P<0.001 ; * * P<0.01 ; * P<0.05$

compounds, in opposition to previous findings (Besle et al., 2010). A larger effect of pasture plant secondary metabolites on milk was expected as well (Leiber et al., 2005). Plant secondary metabolites can partially inhibit ruminal biohydrogenation of herbage PUFA, resulting in a higher concentration of n-3 FA escaping from this rumen pathway and enriching the milk from cows grazing on upland pasture (Collomb et al., 2002b; Leiber et

Table 8. Milk constituents with significant interaction between the season and origin of production ${ }^{1}$

\begin{tabular}{|c|c|c|c|c|c|}
\hline \multirow[b]{2}{*}{ Item } & \multicolumn{2}{|c|}{$\mathrm{O}$} & \multicolumn{2}{|c|}{ I } & \multirow[b]{2}{*}{ Significance } \\
\hline & $\mathrm{L}$ & $\mathrm{U}$ & $\mathrm{L}$ & $\mathrm{U}$ & \\
\hline \multicolumn{6}{|l|}{ Color } \\
\hline $\mathrm{b}$ & $8.96^{\mathrm{a}}$ & $9.38^{\mathrm{a}}$ & $8.08^{\mathrm{b}}$ & $7.17^{\mathrm{c}}$ & $* *$ \\
\hline \multicolumn{6}{|l|}{ Fatty acid (FA; g/100 g of FA) } \\
\hline$\Sigma$ de novo synthesis FA & $24.2^{\mathrm{c}}$ & $23.7^{\mathrm{c}}$ & $25.1^{\mathrm{b}}$ & $25.7^{\mathrm{a}}$ & ** \\
\hline $\mathrm{C} 18: 1$ cis -9 & $19.2^{\mathrm{b}}$ & $19.7^{\mathrm{a}}$ & $18.5^{\mathrm{b}}$ & $18.2^{\mathrm{b}}$ & $*$ \\
\hline C18:3n-3 & $0.53^{\mathrm{b}}$ & $0.61^{\mathrm{a}}$ & $0.45^{\mathrm{b}}$ & $0.43^{\mathrm{b}}$ & $* *$ \\
\hline CLA cis- 9, trans- 11 & $0.71^{\mathrm{b}}$ & $0.85^{\mathrm{a}}$ & $0.42^{\mathrm{c}}$ & $0.44^{\mathrm{c}}$ & $*$ \\
\hline SFA & $68.0^{\mathrm{b}}$ & $66.9^{\mathrm{c}}$ & $70.3^{\mathrm{a}}$ & $70.9^{\mathrm{a}}$ & $* *$ \\
\hline MUFA & $27.5^{\mathrm{b}}$ & $28.1^{\mathrm{a}}$ & $25.9^{\mathrm{c}}$ & $25.4^{\mathrm{c}}$ & $*$ \\
\hline PUFA & $3.82^{\mathrm{b}}$ & $4.22^{\mathrm{a}}$ & $3.31^{\mathrm{c}}$ & $3.27^{\mathrm{c}}$ & ** \\
\hline $\mathrm{C} 18: 1$ cis-9/C16:0 & $0.66^{\mathrm{b}}$ & $0.71^{\mathrm{a}}$ & $0.60^{\mathrm{c}}$ & $0.60^{\mathrm{c}}$ & $*$ \\
\hline \multicolumn{6}{|l|}{ Phenolic compound (ln AAU) } \\
\hline n.i. Rt 51.89 & $4.71^{\mathrm{b}}$ & $7.10^{\mathrm{a}}$ & $2.31^{\mathrm{bc}}$ & $1.39^{\mathrm{c}}$ & ** \\
\hline \multicolumn{6}{|l|}{ Volatile organic compound (ln AAU) } \\
\hline Benzonitrile & $8.25^{\mathrm{ab}}$ & $7.89^{\mathrm{b}}$ & $7.24^{\mathrm{b}}$ & $9.47^{\mathrm{a}}$ & ** \\
\hline Indole & $8.43^{\mathrm{ab}}$ & $7.56^{\mathrm{b}}$ & $7.30^{\mathrm{b}}$ & $9.45^{\mathrm{a}}$ & $*$ \\
\hline 2,3-Octanedione & $11.4^{\mathrm{a}}$ & $11.3^{\mathrm{a}}$ & $10.6^{\mathrm{b}}$ & $11.2^{\mathrm{a}}$ & $*$ \\
\hline$\alpha$-Humulene & $3.39^{\mathrm{b}}$ & $5.86^{\mathrm{a}}$ & $2.67^{\mathrm{a}}$ & $2.46^{\mathrm{a}}$ & $*$ \\
\hline
\end{tabular}

${ }^{a-c}$ Different superscript letters within the same row indicate differences among values.

${ }^{1} \mathrm{O}=$ outdoor season; $\mathrm{I}=$ indoor season; $\mathrm{L}=$ lowland; $\mathrm{U}=$ upland; $\mathrm{b}=$ yellow index; $\mathrm{AAU}=$ arbitrary area unit; $\mathrm{Rt}=$ retention time; $\mathrm{n} . \mathrm{i} .=$ not identified.

${ }^{* *} P<0.01 ;{ }^{*} P<0.05$. 
Table 9. Milk constituents with significant interaction between the forage system and origin of production ${ }^{1}$

\begin{tabular}{|c|c|c|c|c|c|}
\hline \multirow[b]{2}{*}{ Item } & \multicolumn{2}{|c|}{ G } & \multicolumn{2}{|c|}{$\mathrm{C}$} & \multirow[b]{2}{*}{ Significance } \\
\hline & $\mathrm{L}$ & $\mathrm{U}$ & $\mathrm{L}$ & $\mathrm{U}$ & \\
\hline \multicolumn{6}{|l|}{ Fatty acid (FA; g/100 g of FA) } \\
\hline Odd-chain FA & $2.67^{\mathrm{a}}$ & $2.50^{\mathrm{b}}$ & $2.44^{\mathrm{b}}$ & $2.46^{\mathrm{b}}$ & $*$ \\
\hline MUFA & $26.7^{\mathrm{b}}$ & $27.6^{\mathrm{a}}$ & $27.0^{\mathrm{b}}$ & $26.3^{\mathrm{b}}$ & $*$ \\
\hline \multicolumn{6}{|c|}{ Volatile organic compound (ln AAU) } \\
\hline Benzonitrile & $6.76^{\mathrm{b}}$ & $8.72^{\mathrm{a}}$ & $8.94^{\mathrm{a}}$ & $8.31^{\mathrm{a}}$ & $*$ \\
\hline Indole & $6.81^{\mathrm{c}}$ & $8.89^{\mathrm{a}}$ & $9.15^{\mathrm{a}}$ & $7.75^{\mathrm{b}}$ & $* *$ \\
\hline \multicolumn{6}{|l|}{ Production condition } \\
\hline Age at 1st calving (mo) & $32^{\mathrm{a}}$ & $32^{\mathrm{a}}$ & $29^{\mathrm{c}}$ & $30^{\mathrm{b}}$ & $*$ \\
\hline Duration of winter feeding $(\mathrm{d})$ & $160^{\mathrm{b}}$ & $188^{\mathrm{a}}$ & $185^{\mathrm{a}}$ & $189^{\mathrm{a}}$ & $* * *$ \\
\hline
\end{tabular}

al., 2005; De Noni and Battelli, 2008). However, we did not find any difference between upland and lowland $G$ milk in the C18:3n-3 or CLA cis-9,trans-11 concentration during the grazing season. This is probably due to a higher sensitivity of milk FA composition to the fresh herbage proportion in the cow diet and to herbage phenological stage than to the botanical composition in on farm conditions (Coppa et al., 2015c). The phenological stage is also a strong driver of plant secondary metabolite and carotenoid contents in milk (Calderón et al., 2006; Tornambé et al., 2006), and could have diminished the expected differences between the upland and lowland milk composition. Similarly, grazing management can also affect milk carotenoid, terpenoid, and
FA concentrations (Calderón et al., 2006; Tornambé et al., 2006; Coppa et al., 2015b). The supplementation with concentrates as well could have contributed to reduce the differences that were expected regarding the botanical composition of upland pasture (Bovolenta et al., 2009).

\section{Forage System, Season Effects, and Their Interaction}

The effect of feeding systems on milk composition has been largely studied, and the results from the literature are consistent with our findings (Marino et al., 2012; Coppa et al., 2015a; Liu et al., 2018), as well as those
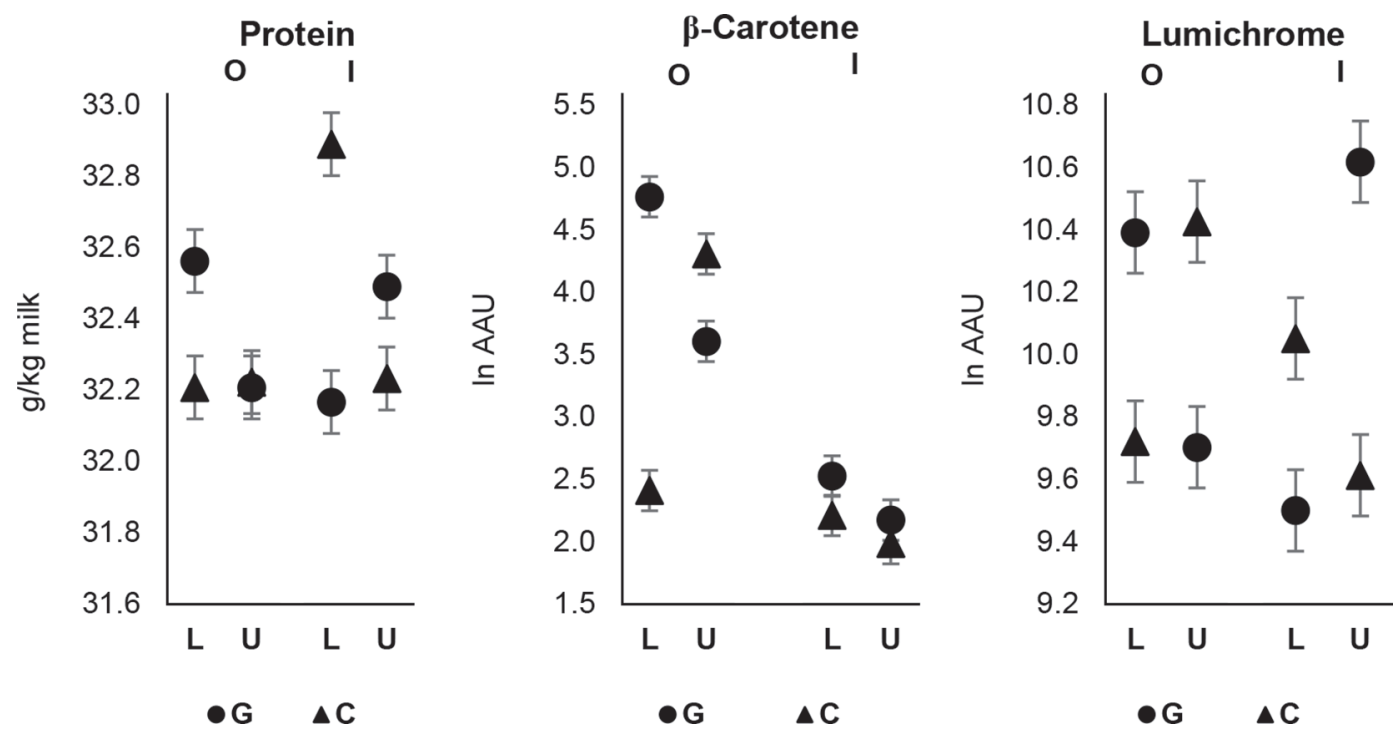

Figure 1. Milk constituents showing significant interactions between season, forage system, and origin $(P<0.05)$. Error bars indicate SEM. $\mathrm{AAU}=$ arbitrary area unit; $\mathrm{G}=$ grass-based forage system; $\mathrm{I}=$ indoor season; $\mathrm{L}=$ lowland; $\mathrm{C}=$ corn silage-based forage system; $\mathrm{O}=$ outdoor season; $\mathrm{U}=$ upland; the lack of overlap between error bars on the y axes indicate significant differences between upland and lowland milk within each forage system for each season. 


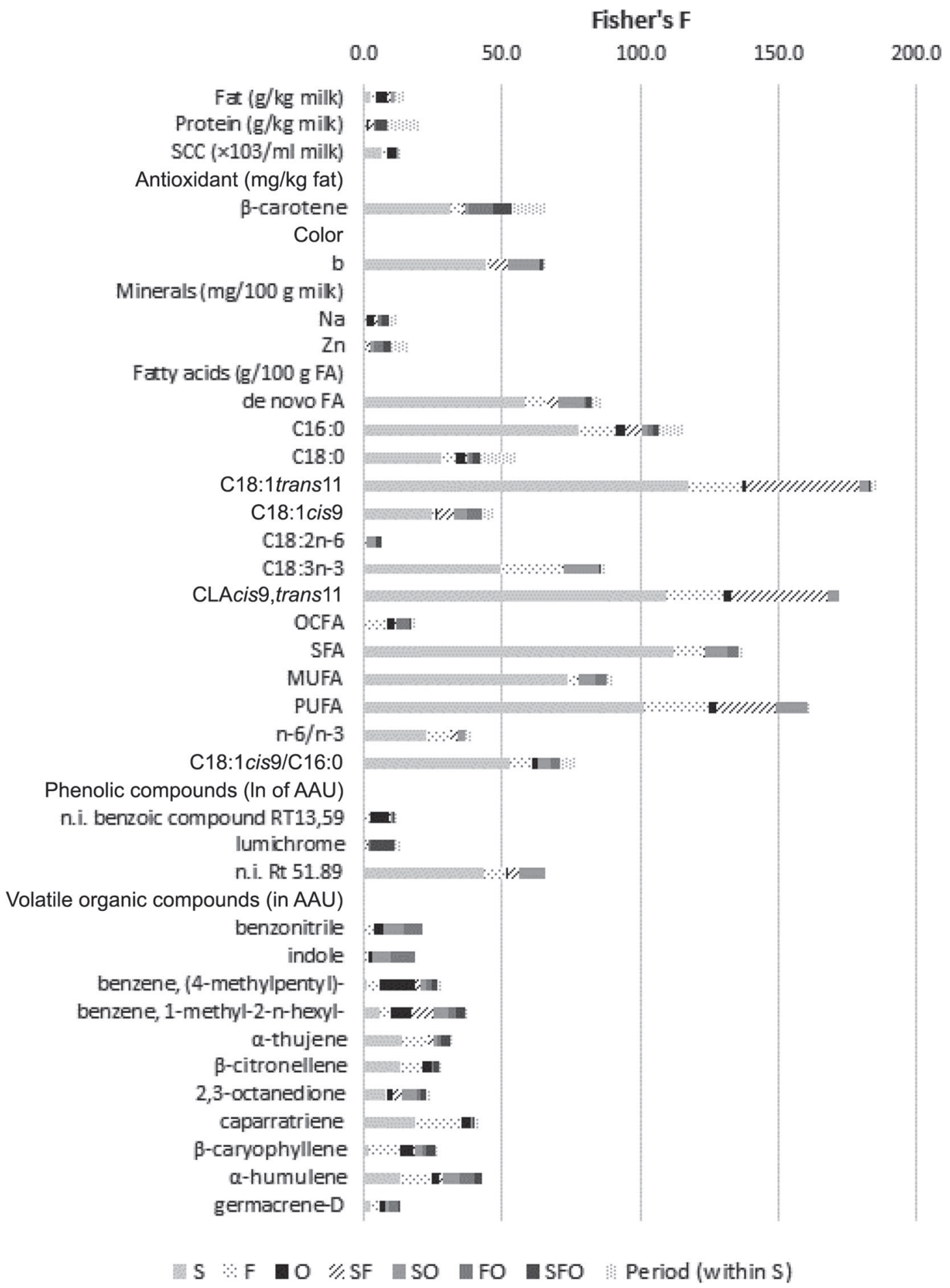

Figure 2. Fisher's $F$ value of the single factors and their interactions included in the statistical model for those milk constituents that showed significant (or numerical; $P<0.1$ ) effect of the origin or of the interactions between origin and other factors. FA $=$ fatty acid; $\mathrm{F}=$ forage system; $\mathrm{O}=$ origin; $\mathrm{S}=$ season; $\mathrm{FO}=$ forage system $\times$ origin; $\mathrm{SF}=$ season $\times$ forage system; $\mathrm{SO}=$ season $\times$ origin; $\mathrm{SFO}=$ season $\times$ forage system $\times$ origin. $\mathrm{OCFA}=$ odd-chain FA; AAU = arbitrary area unit.

from seasonal differences in milk composition, which can be mainly ascribed to changes in cow diet (Agabriel et al., 2007; Butler et al., 2011; Hurtaud et al., 2014).
The cow diet composition (i.e., forage proportion, type and conservation mode, and concentrate amount; Coppa et al., 2015b; Khiaosa-Ard et al., 2015), and par- 
Table 10. Pearson correlation coefficients between the concentration of milk constituents and the proportion of different feedstuffs in dairy cow diets

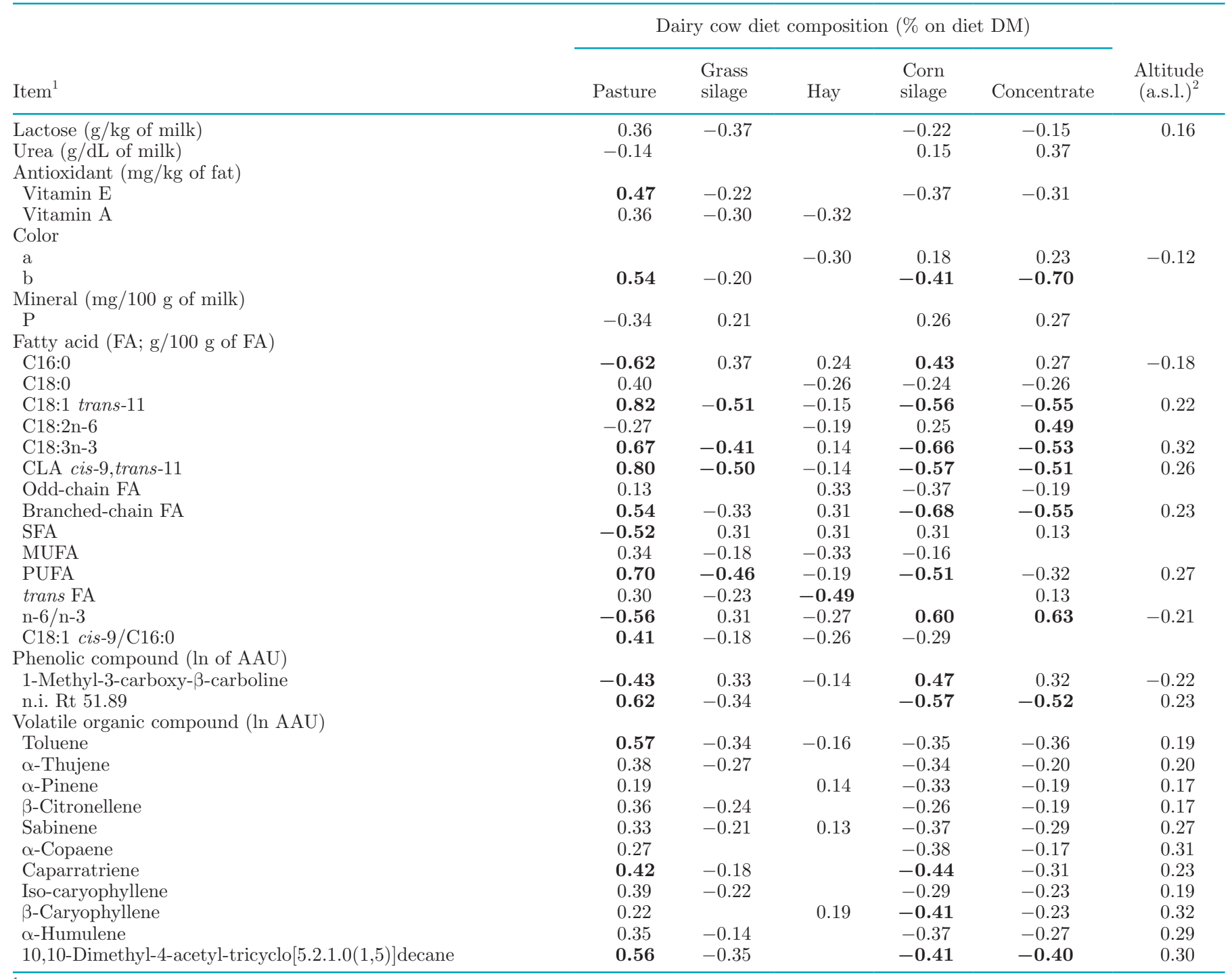

${ }^{1}$ Compounds not showing at least one significant interaction at $P<0.05$ with correlation coefficients between 0.3 and -0.3 are not listed; in bold: correlations coefficients $\geq 0.4$ or $\leq-0.4$. AAU $=$ arbitrary area unit; $\mathrm{a}=$ red index; $\mathrm{b}=$ yellow index; $\mathrm{Rt}=$ retention time; $\mathrm{n}$.i. $=$ not identified. ${ }^{2}$ a.s.l. = above sea level.

ticularly its pasture proportion, was confirmed to be the factor with the greatest effect on milk FA composition (Coppa et al., 2012; Khiaosa-Ard et al., 2015; Bernard et al., 2018), as well as on milk yellowness and vitamin E, toluene, and terpenoid concentrations (Croissant et al., 2007; Engel et al., 2007; Marino et al., 2012). High pasture and low corn silage and concentrate proportions in cow diet were confirmed to positively affect milk composition for the previously cited compounds (Marino et al., 2012; Coppa et al., 2015b; KhiaosaArd et al., 2015). However, the correlations between the fresh herbage proportion and the concentrations of other compounds in milk, such as $\beta$-carotene, 2,3-oc- tanedione, and indoles, known to be markers of pasture feeding, were surprisingly low (Nozière et al., 2006; Coppa et al., 2011; Liu et al., 2018). This could be due to the previously discussed factors interacting with the fresh herbage proportion in the cow diet, including herbage phenology, botanical composition, or grazing management.

A new finding of this study was the positive correlation found in on farm conditions between the fresh herbage proportion in the cow diet and the concentration of n.i. Rt 51.89 UV-absorbing compounds, as well as its negative correlation with corn silage and concentrate proportions in the cow diet. This unidentified com- 
pound was associated with pasture feeding for the first time by Cornu et al. (2009) on experimental farms with different diets. Similarly, the same authors found an indicator of the presence of corn silage presence in the cow diet, identified by Rouge et al. (2013), 1-methyl-3carboxy- $\beta$-carboline. Although this compound should be a marker of grass as well as corn silages, our results validate on farm the findings of Cornu et al. (2009) resulting from a controlled experiment.

\section{Origin and Forage and Feeding Systems Are Strictly Linked}

As the effect of the feeding system on milk composition was largely expected, we specifically built our experimental design to compare lowland and upland milks derived from similar forage systems. This has therefore minimized the differences between upland and lowland groups, which were indeed smaller than expected. It is, however, important to clarify that our results do not call into question the specific composition of upland milk reported by many authors because, in practice, the dominant forage system applied in uplands is very different from that in lowlands. Indeed, when considering the farming system in European upland areas, permanent grasslands consist of $59 \%$ of the used agricultural surface (vs. $33 \%$ on average in the EU). These surfaces often cannot allow any different cultivations and are the basis for ruminant feeding in upland areas (Leiber et al., 2014). Similarly, the share of arable land in the upland regions of the EU is often smaller than $20 \%$ of the agricultural surface, and the surface used for forage production accounts for approximately $73 \%$. Thus, the specific feeding systems for dairy cows in upland areas are mostly grass based, resulting, among other aspects, in a low utilization of human edible feedstuffs (Leiber et al., 2014). As a consequence, the specific composition of upland milk is strictly related to the forage system applied on-farm. Furthermore, the unsuitability of surfaces for machinery and the climatic conditions limit results in an extensive grassland use (Santini et al., 2013; Martin et al., 2014), which favors the conservation of biodiversity and natural landscape, the carbon sequestration in the soil, and ecosystem services in general (D'Ottavio et al., 2018; Bentivoglio et al., 2019). Therefore, a minimal threshold for natural grasslands in the agricultural surface, a limitation of corn silage and concentrates, and the maximization of pasture proportion in the cow diet could be recommended to keep the specific composition of upland dairy products and to consolidate the ecosystem services provided by upland dairy farming systems. This strategy could also be effective to maintain consumers' willingness to pay and liking for upland dairy products.

\section{CONCLUSIONS}

When comparing upland and lowland milk derived from similar forage systems and seasons, this study highlighted that the upland origin per se affected the content of only a few milk constituents. Furthermore, this study allowed to hierarchize the effects related to the origin on milk composition that can be considered as marginal when compared with the effect of season and forage system. However, when significant, the origin effects could be attributable to specific characteristics of upland pasture or derived forages.

\section{ACKNOWLEDGMENTS}

The authors thank the dairy producers in France, Slovakia, and Slovenia for their participation in this study and the French dairy industry, France Contrôle Elevage (Paris, France), Chamber of Agriculture of France (Paris, France), Chamber of Agriculture and Forestry of Slovenia (Ljubljana), and INRA (Paris, France) for their help in milk sampling and farm data collection. Thanks are also due to the France Contrôle Elevage (Paris, France) and Central Cattle Breeding Database (Ljubljana, Slovenia) for free access to the data used in this study. This study was part of the European Research Program Truefood no. 16264 and was funded by the European Commission within the Sixth Framework Program. The work in Slovenia was also co-financed by The Slovenian Ministry of Agriculture and Environment and The Ministry of Education, Science and Sport (V4-0517 and P4-0133; Ljubljana). The French Fonds National d'Aménagement et de Développement du Territoire (FNADT; Lyon, France), the Conseils Régionaux d'Auvergne-Rhône-Alpes (Toulouse, France), de Nouvelle Aquitaine et d'Occitanie (Bordeaux, France), and Conseils départementaux Aveyron (Rodez, France), Creuse (Gueret, France), Corrèze (Tulle, France), Lozère (Mende, France), Haute-Loire (Le Puy-en-Velay, France), and Puy-de-Dôme (ClermontFerrand, France) contributed to the funding. The authors acknowledge the Association des Producteurs de Lait de Montagne (APLM; Rodez, France) and the French government's Initiative D'Excellence and Initiative Science-Innovation-Territoires-Économie (IDEXISITE; Paris, France) initiative 16-IDEX-0001 (CAP 20-25) for fruitful discussions. We would like to thank Magaly Angénieux and Nathalie Kondjoyan from the MASS group (INRA-QuaPA) for technical assistance in the VOC analysis and Isabelle Constant (INRA-UMR Herbivores) for assistance in milk sampling, management, farm surveys, and elaboration of part of the data. A special thanks also to Claire Agabriel to her transversal contribution to the whole project and to 
Odd Magne Harstad for the carotenoids analysis. The authors also thank American Journal Experts Support Team (Durham, NC) for the language revision.

\section{REFERENCES}

Agabriel, C., A. Cornu, C. Journal, C. Sibra, P. Grolier, and B. Martin. 2007. Tanker milk variability according to farm feeding practices: Vitamins A and E, carotenoids, color, and terpenoids. J. Dairy Sci. 90:4884-4896. https://doi.org/10.3168/jds.2007-0171.

Bentivoglio, D., S. Savini, A. Finco, G. Bucci, and E. Boselli. 2019. Quality and origin of mountain foodproducts: The new European label as a strategy for sustainable development. J. Mt. Sci. 16:428 440. https://doi.org/10.1007/s11629-018-4962-x.

Bernard, L., M. Bonnet, C. Delavaud, M. Delosière, A. Ferlay, H. Fougère, and B. Graulet. 2018. Milk fat globule in ruminant: Major and minor compounds, nutritional regulation and differences among species. Eur. J. Lipid Sci. Technol. 120:1700039. https:// doi.org/10.1002/ejlt.201700039.

Besle, J. M., D. Viala, B. Martin, P. Pradel, B. Meunier, J. L. Berdagué, D. Fraisse, J. L. Lamaison, and J. B. Coulon. 2010. Ultraviolet-absorbing compounds in milk are related to forage polyphenols. J. Dairy Sci. 93:2846-2856. https://doi.org/10.3168/jds.2009-2939.

Bovolenta, S., M. Corazzin, E. Saccà, F. Gasperi, F. Biasioli, and W. Ventura. 2009. Performance and cheese quality of Brown cows grazing on mountain pasture fed two different levels of supplementation. Livest. Sci. 124:58-65. https://doi.org/10.1016/j.livsci 2008.12.009.

Bugaud, C., S. Buchin, A. Hauwuy, and J. B. Coulon. 2002. Texture et flaveur du fromage selon la nature du pâturage: Cas du fromage d'Abondance. INRA Prod. Anim. 15:31-36.

Butler, G., S. Stergiadis, C. Seal, M. Eyre, and C. Leifert. 2011. Fat composition of organic and conventional retail milk in northeast England. J. Dairy Sci. 94:24-36. https://doi.org/10.3168/jds.2010 $-3331$.

Calderón, F., G. Tornambé, B. Martin, P. Pradel, B. Chauveau-Duriot, and P. Nozière. 2006. Effects of mountain grassland maturity stage and grazing management on carotenoids in sward and cow's milk. Anim. Res. 55:533-544. https://hal.archives-ouvertes.fr/hal -00890089 .

Chassaing, C., C. Sibra, J. Verbič, O. M. Harstad, J. Golecký, B. Martin, A. Ferlay, I. Constant, C. Delavaud, C. Hurtaud, V. Ž Pongrac, and C. Agabriel. 2016. Mineral, vitamin A and fat composition of bulk milk related to European production conditions throughout the year. Dairy Sci. Technol. 96:715-733. https://doi org/10.1007/s13594-016-0300-7.

Collomb, M., U. Bütikofer, R. Sieber, B. Jeangros, and J. O. Bosset. 2002a. Composition of fatty acids in cow's milk fat produced in the lowlands, mountains and highlands of Switzerland using highresolution gas chromatography. Int. Dairy J. 12:649-659. https:// doi.org/10.1016/S0958-6946(02)00061-4.

Collomb, M., U. Bütikofer, R. Sieber, B. Jeangros, and J. O. Bosset. 2002b. Correlations between fatty acids in cows' milk fat produced in the lowland, mountain and highlands of Switzerland and botanical composition of the fodder. Int. Dairy J. 12:661-666. https://doi .org/10.1016/S0958-6946(02)00062-6.

Coppa, M., C. Chassaing, A. Ferlay, C. Agabriel, C. Laurent, G. Borreani, R. Barcarolo, T. Baars, D. Kusche, O. M. Harstad, J. Verbič, J. Golecký, C. Delavaud, Y. Chilliard, and B. Martin. 2015a. Potential of milk fatty acid composition to predict diet composition and authenticate feeding systems and altitude origin of European bulk milk. J. Dairy Sci. 98:1539-1551. https://doi.org/10.3168/ jds.2014-8794.

Coppa, M., A. Farruggia, P. Ravaglia, D. Pomiès, G. Borreani, A. Le Morvan, and A. Ferlay. 2015b. Frequent moving of grazing dairy cows to new paddocks increases the variability of milk fatty acid composition. Animal 9:604-613. https://doi.org/10.1017/ S1751731114003000.

Coppa, M., A. Ferlay, G. Borreani, A. Revello-Chion, E. Tabacco, G. Tornambé, P. Pradel, and B. Martin. 2015c. Effect of phenological stage and proportion of fresh herbage in cow diets on milk fatty acid composition. Anim. Feed Sci. Technol. 208:66-78. https://doi .org/10.1016/j.anifeedsci.2015.07.006.

Coppa, M., A. Gorlier, M. Lonati, B. Martin, E. M. Russo, and G. Lombardi. 2012. The management of the transition from hay- to pasture-based diets affects milk fatty acid kinetics. Dairy Sci Technol. 92:279-295. https://doi.org/10.1007/s13594-012-0065-6.

Coppa, M., B. Martin, P. Pradel, B. Leotta, A. Priolo, and V. Vasta 2011. Effect of a hay-based diet or different upland grazing systems on milk volatile compounds. J. Agric. Food Chem. 59:4947-4954. https://doi.org/10.1021/jf2005782.

Cornu, A., D. Viala, A. Reynaud, I. Kerveillant, J. M. Besle, and B. Graulet. 2009. Discriminating milks according to cow feeding using phenolic compound profiles. Page 167 in Proc. 16éme Rencontre autours des Recherche sur les Ruminant, Paris, France. Institut de l'élevage, INRA, Paris, France.

Croissant, A. E., S. P. Washburn, L. L. Dean, and D. A. Drake. 2007. Chemical properties and consumer perception of fluid milk from conventional and pasture-based production systems. J. Dairy Sci. 90:4942-4953. https://doi.org/10.3168/jds.2007-0456.

D’Ottavio, P., M. Francioni, L. Trozzo, E. Sedić, K. Budimir, P. Avanzolini, M. F. Trombetta, C. Porqueddu, R. Santilocchi, and M. Toderi. 2018. Trends and approaches in the analysis of ecosystem services provided by grazing systems: A review. Grass Forage Sci 73:15-25. https://doi.org/10.1111/gfs.12299.

De Noni, I., and G. Battelli. 2008. Terpenes and fatty acid profiles of milk fat and Bitto cheese as affected by transhumance of cows on different mountain pastures. Food Chem. 109:299-309. https://doi .org/10.1016/j.foodchem.2007.12.033.

Engel, E., A. Ferlay, A. Cornu, Y. Chilliard, C. Agabriel, G. Bielicki, and B. Martin. 2007. Relevance of isotopic and molecular biomarkers for the authentication of milk according to production zone and type of feeding. J. Agric. Food Chem. 55:9099-9108. https://doi .org $/ 10.1021 / \mathrm{jf0} 0714620$.

Faverdin, P., R. Delagarde, L. Delaby, and F. Mechy. 2007. Alimentation des vaches laitières. Pages 23-55 in Alimentation des bovins, ovins et caprins. Besoins des animaux-Valeurs des aliments. Tables INRA 2007. Quae éditions, Versailles, France.

Ferlay, A., C. Agabriel, C. Sibra, C. Journal, B. Martin, and Y. Chilliard. 2008. Tanker milk variability in fatty acids according to farm feeding and husbandry practices in a French semi-mountain area. Dairy Sci. Technol. 88:193-215. https://doi.org/10.1051/dst: 2007013.

Ferlay, A., L. Bernard, A. Meynadier, and C. Malpuech-Brugère. 2017. Production of trans and conjugated fatty acids in dairy ruminants and their putative effects on human health: A review. Biochimie 141:107-120. https://doi.org/10.1016/j.biochi.2017.08.006.

Giaccone, D., A. Revello-Chion, L. Galassi, P. Bianchi, G. Battelli, M. Coppa, E. Tabacco, and G. Borreani. 2016. Effect of milk thermisation and farming system on cheese sensory profile and fatty acid composition. Int. Dairy J. 59:10-19. https://doi.org/10.1016/ j.idairyj.2016.02.047.

Hurtaud, C., M. Dutreuil, M. Coppa, C. Agabriel, and B. Martin. 2014. Characterization of milk from feeding systems based on herbage or corn silage with or without flaxseed and authentication through fatty acid profile. Dairy Sci. Technol. 94:103-123. https:/ /doi.org/10.1007/s13594-013-0147-0.

ISO. 1998. Milk and milk products - Determination of zinc content - Flame atomic absorption spectrometric method. International Standard ISO 8070. International Organization for Standardization (ISO), Geneva, Switzerland.

ISO/IDF. 2007. Milk and milk products-Determination of calcium, sodium, potassium and magnesium contents-Atomic absorption spectrometric method. ISO 8070:2007 (IDF 119:2007). ISO, Geneva, Switzerland; IDF, Brussels, Belgium.

Khiaosa-Ard, R., M. Kreuzer, and F. Leiber. 2015. Apparent recovery of C18 polyunsaturated fatty acids from feed in cow milk: A meta-analysis of the importance of dietary fatty acids and feeding regimens in diets without fat supplementation. J. Dairy Sci. 98:6399-6414. https://doi.org/10.3168/jds.2015-9459. 
Leiber, F., M. Jouven, B. Martin, A. Priolo, M. Coppa, S. Prache, F. Heckendorn, and R. Baumont. 2014. Potentials and challenges for future sustainable grassland utilisation in animal production. Options Méditerranéennes A. 109:33-48. https://hal.archives -ouvertes.fr/hal-01499073.

Leiber, F., M. Kreuzer, D. Nigg, H. R. Wettstein, and M. R. L. Scheeder. 2005. A study on the causes for the elevated n-3 fatty acids in cows' milk of Alpine origin. Lipids 40:191-202. https://doi.org/10 1007/s11745-005-1375-3.

Liu, N., A. Koot, K. Hettinga, J. de Jong, and S. M. van Ruth. 2018. Portraying and tracing the impact of different production systems on the volatile organic compound composition of milk by PTR(Quad)MS and PTR-(ToF)MS. Food Chem. 239:201-207. https:/ /doi.org/10.1016/j.foodchem.2017.06.099.

Marino, V. M., I. Schadt, S. La Terra, M. Manenti, M. Caccamo, G. Licitra, and S. Carpino. 2012. Influence of season and pasture feeding on the content of $\alpha$-tocopherol and $\beta$-carotene in milk from Holstein, Brown Swiss and Modicana cows in Sicily. Dairy Sci. Technol. 92:501-513. https://doi.org/10.1007/s13594-012-0069-2.

Martin, B., M. Lherm, and C. Béranger. 2014. Evolutions et perspectives de l'élevage des ruminants dans les montagnes françaises. INRA Prod. Anim. 27:5-16.

Martin, B., I. Verdier-Metz, S. Buchin, C. Hurtaud, and J. B. Coulon. 2005. How does the nature of forages and pastures diversity influence the sensory quality of dairy livestock products? Anim. Sci. 81:205-212. https://doi.org/10.1079/ASC50800205.

Mazzocchi, C., and G. Sali. 2016. Sustainability and competitiveness of agriculture in mountain areas: A willingness to pay (WTP) approach. Sustainability 8:343. https://doi.org/10.3390/su8040343.

Nozière, P., B. Graulet, A. Lucas, B. Martin, P. Grolier, and M. Doreau. 2006. Carotenoids for ruminants: From forages to dairy products. Anim. Feed Sci. Technol. 131:418-450. https://doi.org/ 10.1016/j.anifeedsci.2006.06.018.

Palanuk, S. L., and J. J. Warthesen. 1988. The kinetics of lumichrome in skim milk using nonlinear regression analysis. Food Chem. 27:115-121. https://doi.org/10.1016/0308-8146(88)90083-0.

Ratel, J., and E. Engel. 2009. Determination of benzenic and halogenated volatile organic compounds in animal-derived food products by one-dimensional and comprehensive two-dimensional gas chromatography-mass spectrometry. J. Chromatogr. A 1216:78897898. https://doi.org/10.1016/j.chroma.2009.09.012.

Reynaud, A., D. Fraisse, A. Cornu, A. Farruggia, E. Pujos-Guillot, J. M. Besle, B. Martin, J. L. Lamaison, D. Paquet, M. Doreau, and B. Graulet. 2010. Variation in content and composition of phenolic compounds in permanent pastures according to botanical variation. J. Agric. Food Chem. 58:5485-5494. https://doi.org/10 $.1021 / \mathrm{jf1000293.}$

Romanzin, A., M. Corazzin, S. Favotto, E. Piasientier, and S. Bovolenta. 2015. Montasio cheese liking as affected by information about cows breed and rearing system. J. Dairy Res. 82:15-21. https://doi .org/10.1017/S0022029914000545.

Rouge, P., A. Cornu, A. S. Biesse-Martin, B. Lyan, N. Rochut, and B. Graulet. 2013. Identification of quinolone, carboline and glycinamide compounds in cow milk using HRMS and NMR. Food Chem. 141:1888-1894. https://doi.org/10.1016/j.foodchem.2013 .04 .072 .

Santini, F., F. Guri, and S. Gomez y Paloma. 2013. Labelling of agricultural and foodproducts of mountain farming. Page 159 in EUR Scientific and Technological Series. European Commission, EUR 25768 Joint Research Centre-Institute for Prospective Technological Studies, Seville, Spain.

Segato, S., G. Galaverna, B. Contiero, P. Berzaghi, A. Caligiani, A. Marseglia, and G. Cozzi. 2017. Identification of lipid biomarkers to discriminate between the different production systems for Asiago PDO cheese. J. Agric. Food Chem. 65:9887-9892. https://doi.org/ 10.1021/acs.jafc.7b03629.

Sexton, K., J. L. Adgate, T. R. Church, D. L. Ashley, L. L. Needham, G. Ramachandran, A. L. Fredrickson, and A. D. Ryan. 2005 Children's exposure to volatile organic compounds as determined by longitudinal measurements in blood. Environ. Health Perspect. 113:342-349.

Tornambé, G., A. Cornu, P. Pradel, N. Kondjoyan, A. P. Carnat, M. Petit, and B. Martin. 2006. Changes in terpene content in milk from pasture-fed cows. J. Dairy Sci. 89:2309-2319. https://doi .org/10.3168/jds.S0022-0302(06)72302-5.

Verdier-Metz, I., J. B. Coulon, P. Pradel, C. Viallon, H. Albouy, and J. L. Berdagué. 2000. Effect of botanical composition of hay and casein genetic variants on the chemical and sensory characteristics of ripened Saint-Nectaire type cheese. Lait 80:360-370. https://doi .org/10.1051/lait:2000131.

Viallon, C., B. Martin, I. Verdier-Metz, P. Pradel, J. P. Garel, J. B. Coulon, and J. L. Berdagué. 2000. Transfer of monoterpenes and sesquiterpenes from forages into milk fat. Lait 80:12-16. https:// doi.org/10.1051/lait:2000150.

Wania, F., and J. N. Westgate. 2008. On the mechanism of mountain cold-trapping of organic chemicals. Environ. Sci. Technol. 42:90929098. https://doi.org/10.1021/es8013198. 